\title{
Wetlands In Northern Plains Prairies: Benefitting Wildlife \& Livestock
}

\section{Prairie wetlands are often viewed as nuisances by the farming community, but provide valuable habitat for wildlife and livestock alike.}

\author{
By Donald R. Kirby, Kelly D. Krabbenhoft, Kevin K. Sedivec and Edward S. DeKeyser
}

$\mathrm{W}$ etlands, or prairie potholes as they are commonly called, are distinctive features of the Northern Great Plains. This is an area approximately 900 miles long and 500 miles wide. From east to west it stretches between the foothills of the Rocky Mountains and the $100^{\text {th }}$ meridian, and from south to north between the North Platte River and the Boreal Forest of Canada.

Much of the topography of the Northern Great Plains north and east of the Missouri River is dotted with shallow basins following glacial advances and retreats. It is this region of glacial deposits interspersed with shallow basins that has been named the Prairie Pothole Region. The Pothole Region of the plains encompasses nearly 300,000 square miles from central Alberta to southern South Dakota and central Iowa.

Most of the shallow basins of this region hold surface water for only short periods of time allowing many to be intensively cultivated. In a report to Congress, Dahl (1990) estimated in the 1980 's that $50 \%$ ( 2.5 million acres) and $65 \%$ (1.8 million acres), respectively, of the natural wetlands in North and South Dakota remained.

Wetlands in the Pothole Region are generally classified using the system developed specifically for this glaciated region by Stewart and Kantrud (1971). Most wetlands using this system fall into temporary, seasonal, semi-permanent and permanent wetlands based on water permanence with an increasing number of corresponding vegetative zones termed wet meadow, shallow marsh and deep marsh.

Wetlands perform a range of societal services by providing for direct and indirect human use, wildlife, and environmental maintenance. We will examine two major ecological functions wetlands perform in northern prairie complexes: (1) Wildlife Habitat and (2) Forage. On page, 25 we will discuss societal contributions of prairie wetlands.

\section{Wildlife Habitat}

A wide array of wildlife utilize wetlands depending upon seasonal and annual water level fluctuations, as well as disturbances such as grazing and fire. From severe floods to devastating droughts, extremes are commonplace within the Prairie Pothole region. Due to these cyclic climatic patterns, a single wetland may have a drastically different wildlife composition from year to year.

A reduction in natural ecological processes such as grazing, fire and water-level fluctuations contribute to decreased habitat diversity. Without disturbance dense stands of plants such as cattails become dominant in numerous wetlands. Unless unusually severe, livestock grazing of wetlands results in increased plant species diversity, more complex plant distribution patterns and more defined zonal boundaries. Decreased use of prairie wetlands by aquatic birds is often attributed to a decrease in habitat diversity. Duck production on four specialized grazing systems in south-central North Dakota was 1.5 to
2 times the level believed necessary to sustain a population. Average forage utilization by livestock ranged from 54 to $62 \%$ on the grazing treatments during the five-year study.

Wetlands are best known for the waterfowl population they support. The Prairie Pothole Region comprises only about $10 \%$ of North America's wetland breeding area, but produces nearly $50 \%$ of the waterfowl in any given year. During years of above average precipitation, this percentage may be even higher. Estimates for total breeding duck populations in North America can be found in Figure 1.

The last two decades of the 20th century exhibited drastic waterfowl population changes. As the 1980's came to a close, a severe drought occurred in the Northern Plains. Decreased wetland habitat and increased predation were significant factors limiting waterfowl production. Since 1993, above average precipitation has increased waterfowl populations, though not for all species, to modern day high levels.

Other factors that have assisted the waterfowl recovery include the: 1) North American Waterfowl Management Plan; 2) U.S. Department of Agriculture's Conservation Reserve Program; and 3) U. S. Prairie Pothole Joint Venture.

Waterfowl use of wetland habitats can be placed in four broad categories.

- Courtship

- Brood raising

- Fall migration

- Drought 
Each category can be associated with one or more wetland classes. For example, temporary and seasonal wetland abundance is critical during female mallard pre-nesting and egg production. These wetlands are first to become ice-free and provide display areas for attracting mates plus these are protein rich in insect populations needed for egg production. Brood raising occurs in those wetland habitats that contain the best combination of cover and food availability. Semi-permanent wetlands are used most often during this period as cover and water amounts provide safe conditions for raising newly hatched young. During wet years, seasonal wetlands also have provided waterfowl with attractive brood raising habitat.

During fall migration, water availability is usually restricted to permanent wetlands as the semi-permanent wetlands have dried up. Many waterfowl species feed in surrounding grain fields and use open water to rest. Open-water habitat becomes restricted during periods of drought. As temporary and seasonal wetland habitats dry up, semi-permanent wetlands sustain the waterfowl population. If drought continues for multiple years, dry wetland basins within cropland are often cultivated and seeded leading to declines in waterfowl populations.

\section{Forage Provided Too}

While wetlands provide critical habitat for waterfowl and other wildlife species they can also provide valuable forage for livestock, either in a haying or grazing program. Forage production of vegetation in wetlands usually exceeds production on upland sites. However, wetland forage generally has lower crude protein and digestible dry matter content making it less valuable as livestock feed.

If harvested or grazed early-season (before heading), the dominant grasses and sedges of temporary wetlands can make nutritious forage.

\section{Total Breeding Duck Population Estimates}

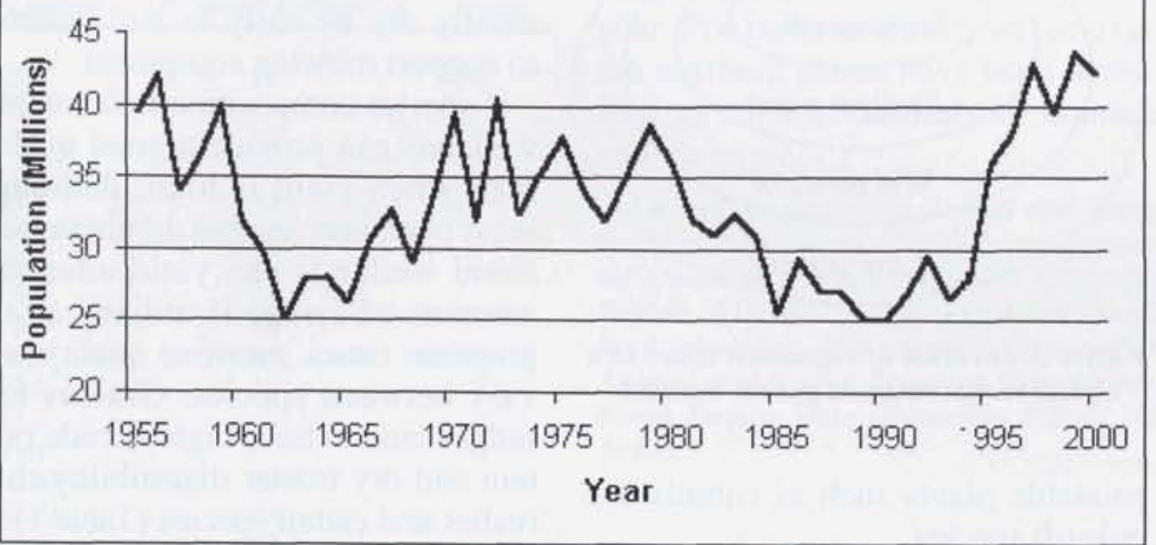

Figure 1. Estimated total breeding duck population (Mallard, Gadwall, American Wigeon, Green-winged teal, Blue-winged teal, Northern shoveler, Northern pintail, Redhead, Canvasback and Scaup) for North America from 1955-2000 (modified from Wilkins et al. 2000).

However, early season yields will be less than at mid-season (July and August) use. Wetland vegetation production steadily increases through mid July, peaking through August, and declining in September. Forage quantity and quality will vary with species composition, which is directly related to wetland type and zonation.

Grass and grasslike plants usually provide the highest quality forage, including nutrient content and palatability. Dry matter production of wetland vegetation will vary be-

tween wetland class and zone, with the greatest production associated with semi-permanent wetlands having little or no open water.

While wet meadow zones produce one-half to one-third the production of shallow marsh and deep marsh zones, respectively, they are the most frequently used forage area. Favorable forages such as grasses and sedges dominate wet meadow zones; whereas, less palatable plants such as rushes become prevalent in shallow marsh zones. Deep marsh zones become dominated by lower

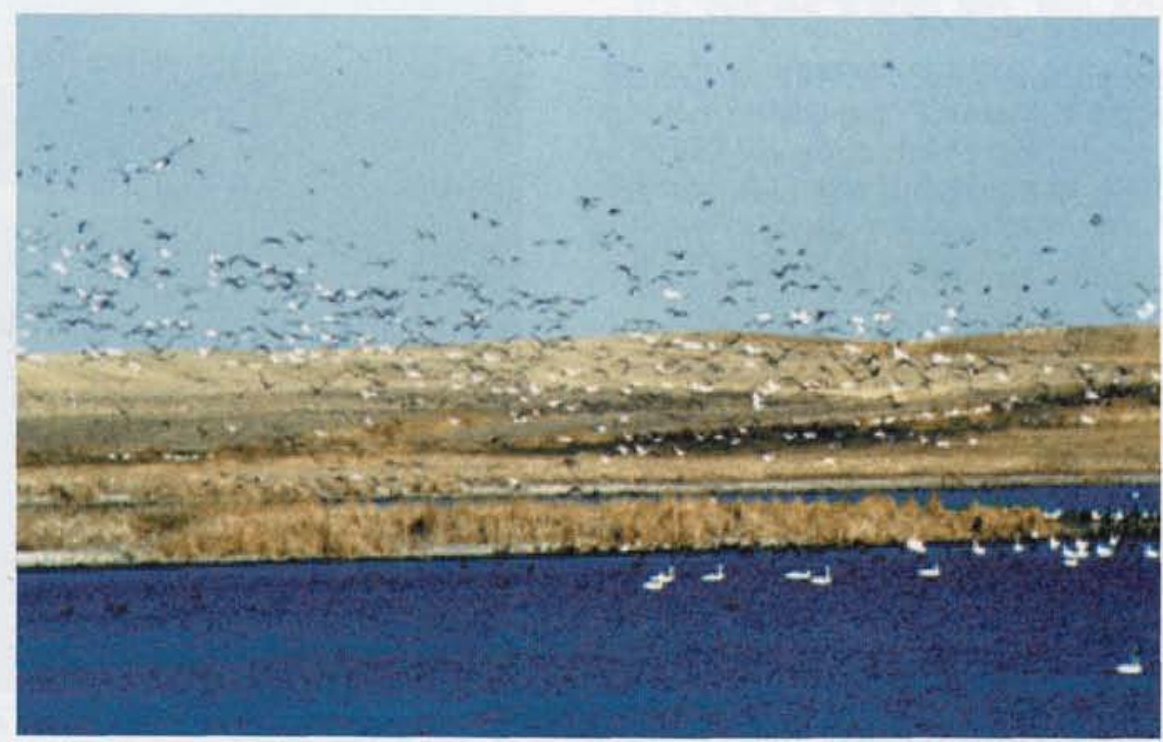

Figure 2. Millions of migrating waterfowl annually use prairie wetlands. 


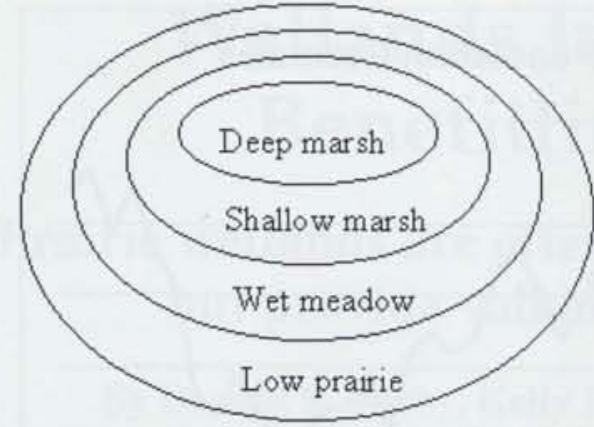

Figure 3. Location of vegetation zones in a typical semipermanent prairie wetland.

palatable plants such as cattails and bulrush species.

In the Dakota's, dry matter production levels vary from 1 to 2 tons per acre on wet meadow zones, 1.5 to 3.5 tons per acre on shallow marsh zones, and 2.5 to 6.5 tons per acre on deep marsh zones. Peak yields of slough sedge have been reported to range from 2.0 to 4.7 tons per acre in North Dakota to nearly 10 tons per acre in Iowa.

Manipulation of water levels and vegetative structure can alter forage production and species composition of wetlands. Reductions of litter through prescribed burning, mowing or intense midsummer grazing programs have also increased yields of wetland stands. Disturbance programs not only produce substantial yields, but have altered pure stands of species such as rushes or cattails to diverse plant communities that improve quantity or quality of forage produced. Production of whitetop was increased to 5.2 tons per acre using fall burning and 4.5 tons per acre by mowing compared to 3.2 tons per acre from undisturbed stands.

Although livestock producers have consistently utilized aquatic plants as forage, little attention has been attributed to nutritive content. Crude protein and digestible dry matter tend to be lower from wetland forage than upland prairie. Seasonal wetlands provide the best quality forage compared to other wetland types. However, like most wetland areas, seasonal wetland soils tend to be too wet for livestock or equipment to get into when quality is optimum. These soils tend to become sufficiently dry by early to mid summer to support mowing equipment.

If species composition is favorable, wetlands can provide a good quality feed when yield is high. Although most plant species that dominate seasonal wetlands can yield adequate amounts of forage if utilized at appropriate times, nutritive quality will vary between species. Grasses and sedges tend to have higher crude protein and dry matter digestibility than rushes and cattail species (Table 1).

Nutrient quality of wetland plants declines with maturity, similar to upland prairie plants. Most wetland grasses have slightly lower protein and digestibility, higher fiber and similar phosphorus and calcium content when compared to upland prairie grasses. However, nutrient loss has been found to be greater in upland species than wetland species as the growing season progressed and wetland hays have been reported superior to upland hay in maintaining quality during dry years.

Palatability is a major concern when determining the overall use and importance of wetland vegeta-

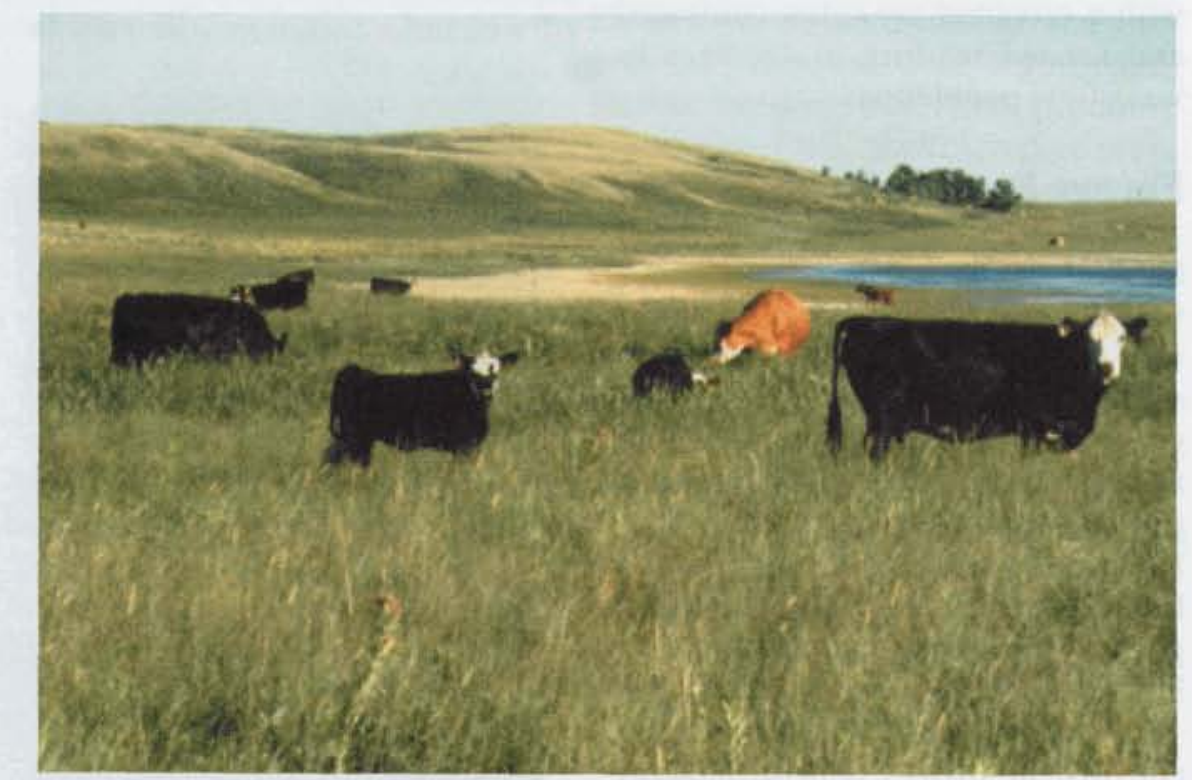

Figure 4. Wetlands are an integral part of prairie landscapes providing forage and water

for the livestock industry.

tion. Wetland plant species will vary dramatically in palatability. Palatability will also differ for some plant species due to timing of harvest. Knowing the level of a plants palatability, which plants are palatable early (prior to heading) but not palatable once mature, and those that are unpalatable or low in palatability will help to fully utilize wetland plants in a livestock feeding program. Although a feed or forage may have high palatability, nutritional quality must be adequate to maintain livestock performance or body condition.

Many wet meadow and wetland plants are as nutritious as upland vegetation; however, digestibility drops off dramatically as plants mature, even when crude protein remains high. Many wetland plants, when fed as hay or grazed, tend to have a laxative effect in livestock. Knowing the quantity and quality of wetland forages is essential for best use in a feeding program.

In all, wetlands provide habitat for a variety of animals including wildlife and domestic livestock. Some wildlife species, such as waterfowl, are completely dependent on wetlands for food, protection, resting areas and water. Other ani- 
Table 1. Nutrient content of emergent plants found in prairie wetlands (based on $100 \%$ dry matter).

\begin{tabular}{|c|c|c|c|c|}
\hline Species & Date & Crude protein & Dry matter digestibility & Source \\
\hline \multicolumn{5}{|l|}{ Grass-like Plants } \\
\hline Broad-leaved cattail & $10 \mathrm{June}$ & 15.1 & 52 & 6 \\
\hline \multirow[t]{3}{*}{ (Typha latifolia) } & $15 \mathrm{July}$ & 3.8 & --- & \\
\hline & 15 August & 2.8 & 27 & \\
\hline & 16 September & 3.5 & $-\cdots$ & \\
\hline Hardstem bulrush & 6 June & 12.5 & 53 & 4 \\
\hline (Scirpus acutus) & 15 August & 8.8 & 37 & \\
\hline Baltic rush & 26 June & 15.6 & 42 & $2,4,9$ \\
\hline \multirow[t]{3}{*}{ (Juncus balticus) } & $23 \mathrm{July}$ & 8.7 & 28 & \\
\hline & 4 August & 9.2 & 28 & \\
\hline & 12 August & 7.2 & 23 & \\
\hline Spikerush & 24 May & 22.1 & 60 & 2,4 \\
\hline \multirow[t]{3}{*}{ (Eleocharis palustris) } & 21 June & 11.2 & ----- & \\
\hline & $13 \mathrm{July}$ & 11.4 & ----- & \\
\hline & 4 August & 7.4 & 38 & \\
\hline Needle spikerush & 6 June & 11.8 & 63 & 4 \\
\hline \multirow[t]{2}{*}{ (E. acicularis) } & 21 July & 8.4 & 47 & \\
\hline & 4 August & 8.0 & 43 & \\
\hline Slough sedge & 10 June & 13.5 & 56 & 4 \\
\hline \multirow[t]{3}{*}{ (Carex atherodes) } & $11 \mathrm{July}$ & 9.4 & 40 & \\
\hline & 4 August & 7.4 & 37 & \\
\hline & 21 August & 7.5 & 31 & \\
\hline Wooly sedge & 6 June & 11.4 & 55 & 4 \\
\hline \multirow{2}{*}{ (C. lanuginosa) } & $8 \mathrm{July}$ & 9.1 & 39 & \\
\hline & 15 August & 7.7 & 30 & \\
\hline Praegracilis sedge & 15 June & 10.5 & 50 & 4,8 \\
\hline \multirow[t]{2}{*}{ (C. praegracilis) } & 28 July & 7.8 & 41 & \\
\hline & 4 November & 3.6 & ----- & \\
\hline \multicolumn{5}{|l|}{ Grass Plants } \\
\hline Common reed & $6 \mathrm{June}$ & 16.3 & 52 & \\
\hline \multirow[t]{2}{*}{ (Phragmites australis) } & 25 July & 9.9 & 42 & \\
\hline & 15 August & 9.1 & 43 & 4 \\
\hline Northern reedgrass & 2 June & 18.8 & 59 & \\
\hline (Calamagrostis inexpensa) & 10 August & 7.1 & 45 & 1,2 \\
\hline Reed canarygrass & 6 June & 16.2 & 56 & \\
\hline \multirow[t]{2}{*}{ (Phalaris arundinacea) } & 4 August & 5.2 & 43 & $4,5,6$ \\
\hline & 16 September & 4.1 & $-\ldots--$ & \\
\hline Tall mannagrass & 6 June & 14.6 & 67 & \\
\hline \multirow[t]{2}{*}{ (Glyceria grandis) } & 25 July & 10.9 & 35 & \\
\hline & 15 August & 6.4 & 33 & 4 \\
\hline Hollowstem, whitetop & 6 June & 18.4 & 54 & \\
\hline \multirow[t]{2}{*}{ (Scolochloa festucacea) } & 7 July & 9.9 & 39 & $1,4,10$ \\
\hline & 15 September & 5.3 & 27 & \\
\hline American sloughgrass & 21 June & 11.2 & 47 & \\
\hline \multirow[t]{3}{*}{ (Beckmannia syzigachne) } & 27 July & 9.3 & ----- & \\
\hline & 4 August & 8.8 & 41 & $2,4,9$ \\
\hline & 7 September & 7.5 & ----- & \\
\hline Prairie cordgrass & 6 June & 14.9 & 53 & \\
\hline (Spartina pectinata) & 4 August & 8.7 & 40 & 4 \\
\hline & 23 August & 7.4 & -..-- & \\
\hline & 26 September & 6.4 & ----- & \\
\hline Foxtail barley & 24 June & 24.0 & $-\cdots$ & \\
\hline (Hordeum jubatum) & $26 \mathrm{July}$ & 10.4 & ----- & 2 \\
\hline Inland saltgrass & 4 June & 15.1 & ---- & \\
\hline (Distichlis spirata) & $16 \mathrm{July}$ & 10.2 & ---- & \\
\hline & 18 August & 7.5 & $\cdots$ & 2 \\
\hline Broad-leaf Plants & & & & \\
\hline Long-rooted smartweed & 3 June & 14.8 & 65 & \\
\hline (Polygonum coccineum) & 22 July & 7.1 & 36 & 4 \\
\hline & 21 August & 13.2 & 28 & \\
\hline Giant bur-reed & 6 June & 16.5 & 41 & \\
\hline (Sparganium eurycarpum) & 4 August & 11.5 & 34 & 4,11 \\
\hline & 1 September & 7.6 & --- & \\
\hline Water Plantain & $1 \mathrm{July}$ & 34.3 & $-\cdots-$ & \\
\hline (Alisma plantago-aquatica) & 1 September & 14.8 & ----- & 3,7 \\
\hline
\end{tabular}

Sources: 1) Christensen et al. 1947, 2) Clark and Tisdale 1945, 3) Gortner 1934, 4) Green 1987, 5) Hawley et al. 1981, 6) Klopatek 1975, 7) Korelykova 1970, 8) Mclean and Tisdale 1960, 9) Knight et al. 1906, 10) Smith 1973, 11) Linn er al. 1975 . mal species such as domestic livestock are dependent on wetlands only for a portion of a season or year. For both, however, wetlands of the northern plains have been identified as critical habitats to manage and maintain.

Authors are professor, Animal and Range Sciences Department at NDSU; environmental specialist, Coteau Properties Company, Beulah, ND 58523; state extension rangeland specialist, and rangeland specialist, Animal and Range Sciences Department, North Dakota State University, Fargo, ND 58105.

\section{References}

Barker, W.T., K.K. Sedivec, T.A. Messmer, K.F. Higgins, and D.R. Hertel. 1990. Effects of specialized grazing systems on waterfowl production in southcentral North Dakota. In: Trans. $55^{\text {th }}$ N. A. Wildl, and Nat. Res. Conf. p. 462-474

Dahl, T.E. 1990. Wetland losses in the United States: 1780 s to 1980 s. U.S. Dept. of the Interior, Wash., DC.

Fulton, G.W., J.L. Richardson, and W.T. Barker. 1986. Wetland soils and vegetation. North Dakota Agri. Exp. Sta. Res. Rep. 106.

Hubbard, D.H. 1988. Using your wetland for forage. Rep. FS-853. U.S. Fish and Wildlife Res. Unit, South Dakota State Univ., U.S. Dept. of Agri., Brookings, SD.

Kantrud, H.A., G.L. Krapu, and G.A. Swanson. 1989. Prairie basin wetlands of the Dakotas: A community profile. U.S. Fish and Wildlife Serv. Biol. Rep. 85. $111 \mathrm{pp}$.

Smith, A.L. 1973. Production and nutrient status of whitetop. J. Range Manage. 26:117-120.

Stewart, R.E. and H.A. Kantrud. 1971. Classification of natural ponds and lakes in the glaciated prairie region. U.S. Fish and Wildlife Serv. Resource Publ. 92. 57 pp.

Van der Valk, A.G. and C.B. Davis. 1978. Primary production of prairie glacial marshes. in R.E. Good, D.F. Whigham and R.L. Simpson (eds.). Freshwater wetlands: Ecological processes and management potential. Academic Press, NY.

Wilkins, K.A., M.C. Otto, and G.W. Smith. 2000. Trends in duck breeding populations, 1955-2000. Admin. Rpt., U.S. Fish and Wildlife Serv., Laurel, MD. 19 pp. 